\title{
Analisis Jaringan Kantor dan Pertumbuhan Tenaga Kerja Terhadap Total Aset Unit Usaha Syariah Tahun 2019
}

\author{
Faraniena Yunaeni Risdiana \\ Institut Agama Islam Negeri Madura \\ Jl. Raya Panglegur KM. 4, Pamekasan \\ e-mail: frisdiana@iainmadura.ac.id
}

\begin{abstract}
ABSTRAK
Perkembangan Aset unit usaha syariah di indonesia di pengaruhi oleh dua faktor yakni Jaringan kantor dan pertumbuhan tenaga kerja. Data penelitian merupakan data sekunder hasil publikasi Otoritas Jasa Keuangan pada tahun 2019. Untuk menguji pengaruh tersebut digunakan model regresi linier berganda. Hal ini dijustifikasi oleh hasil uji ANOVA yang menunjukkan bahwa terdapat hubungan jaringan kantor dan tenaga kerja dan terhadap perkembangan aset unit usaha syariah syariah. Ini terlihat dari nilai pvalue nya sebesar $0,005<\alpha(0,05)$, pengujian yang dilakukan untuk mengetahui secara bersama-sama variabel bebas berpengaruh secara signifikan atau tidak terhadap variabel terikat. Sehingga dapat dikatakan bahwa jaringan kantor dan pertumbuhan tenaga kerja terhadap perkembangan aset unit usaha syariah memiliki hubungan.
\end{abstract}

Kata kunci : Aset Unit Usaha Syariah, Jaringan Kantor, Tenaga Kerja Otoritas Jasa Keuangan, Regresi Linear Berganda.

\begin{abstract}
The development of sharia business unit assets in Indonesia is influenced by two factors namely the office network and workforce growth. The research data are secondary data from the publication of the Financial Services Authority in 2019. To test this effect a multiple linear regression model was used. This is justified by the ANOVA test results which show that there is a relationship between the office and labor network and the development of sharia business unit assets. This can be seen from the p-value of $0,005<\alpha$ (0.05), testing conducted to determine together the independent variables significantly or not influence the dependent variable. So it can be said that the office network and workforce growth towards the development of sharia business unit assets have a relationship.

Keywords : Sharina Business Unit Assets, Office Networks, Labor Growth, Financial Services Authority, Multiple Linear Regression.
\end{abstract}

\section{PENDAHULUAN}

Di zaman era globalisasi sekarang ini perekonomian menjadi tolok ukur bagi kemajuan suat negara. Perekonomian yang maju dapat ditandai dengan tumbuh dan berkembangnya segala bidang perekonomian secara signifikan. Salah satu perkembangan tersebut dapat dibuktikan dalam bidang perbankan. Hal ini terlihat dengan banyak bermunculan bank kontemporer berbasis syariah.

Perbankan Syariah adalah segala sesuatu yang menyangkut tentang Bank Umum Syariah (BUS), Bank Pembiayaan Rakyat Syariah (BPRS) dan Unit Usaha Syariah (UUS), mencakup kelembagaan, kegiatan usaha, serta cara dan proses dalam melaksanakan kegiatan usahanya berdasarkan prinsip syariah seperti prinsip keadilan dan keseimbangan ('adl wa tawazun), kemaslahatan (maslahah), universalisme (alamiyah), serta tidak mengandung gharar, maysir, riba, zalim dan obyek yang haram. Selain itu, UU Perbankan Syariah juga mengamanahkan bank syariah untuk menjalankan fungsi sosial dengan menjalankan fungsi seperti lembaga baitul mal, yaitu menerima dana yang berasal dari zakat, infak, sedekah, hibah, atau dana sosial lainnya dan menyalurkannya kepada pengelola wakaf (nazhir) sesuai kehendak pemberi wakaf (wakif). Prinsip syariah merupakan prinsip hukum Islam dalam kegiatan perbankan syariah berdasarkan fatwa yang dikeluarkan oleh Dewan Syariah Nasional-Majelis Ulama Indonesia (DSNMUI).

Unit Usaha Syariah, yang selanjutnya disebut UUS adalah unit kerja dari kantor pusat Bank Umum Konvensional (BUK) yang berfungsi sebagai kantor induk dari kantor atau unit yang melaksanakan kegiatan usaha berdasarkan prinsip syariah, atau unit kerja di kantor cabang dari suatu Bank yang berkedudukan di luar negeri yang melaksanakan kegiatan usaha secara konvensional 
yang berfungsi sebagai kantor induk dari kantor cabang pembantu syariah/atau unit syariah. Berikut ini (dalam Peraturan Bank Indonesia Nomor 15/14/PBI/2013 Tentang Unit Usaha Syariah) ada beberapa: istilah penting lainnya yang perlu dipahami berkaitan dengan UUS, yaitu:

1. Kantor Cabang Syariah (KCS) Kantor Cabang Syariah (KCS) adalah kantor UUS yang bertanggung jawab kepada UUS pada BUK, dengan alamat tempat usaha yang jelas sesuai dengan lokasi KCS tersebut melakukan usahanya, termasuk kantor cabang pembantu syariah dari suatu bank yang berkedudukan di luar negeri.

2. Kantor Cabang Pembantu Syariah (KCPS) Kantor Cabang Pembantu Syariah (KCPS) adalah kantor UUS yang kegiatan usahanya membantu KCS induknya, dengan alamat usaha yang jelas sesuai dengan lokasi KCPS tersebut melakukan usahanya, termasuk kantor cabang pembantu syariah atau kantor kas dari suatu bank yang berkedudukan di luar negeri.

3. Kantor Kas Syariah (KKS)

Kantor Kas Syariah (KKS) adalah kantor UUS yang kegiatan usahanya membantu KCS atau KCPS induknya, kecuali melakukan penyaluran dana, dengan alamat tempat usaha yang jelas sesuai dengan lokasi KKS tersebut melakukan usahanya.

4. Layanan Syariah (LS)

Layanan Syariah (LS) adalah kegiatan penghimpunan dana, pembiayaan, dan pemberian jasa perbankan lainnya berdasarkan prinsip syariah yang dilakukan di kantor cabang konvensional atau kantor cabang pembantu konvensional untuk dan atas nama KCS pada bank yang sama.

5. Kegiatan Pelayanan Kas Syariah (KPKS) Kegiatan Pelayanan Kas Syariah (KPKS) adalah kegiatan kas dalam rangka melayani pihak yang telah menjadi nasabah UUS meliputi antara lain:

a. Kas Keliling: kegiatan pelayanan kas secara berpindah-pindah dengan menggunakan alat transportasi atau pada lokasi tertentu secara tidak permanen, antara lain kas mobil, kas terapung atau counter bank non permanen.

b. Payment Point (PP): kegiatan dalam bentuk penerimaan pembayaran melalui kerjasama antara BUK yang memiliki UUS dengan pihak lain pada suatu lokasi tertentu, seperti untuk penerimaan pembayaran tagihan telepon, tagihan listrik dan/atau penerimaan setoran dari pihak ketiga. c. Perangkat Perbankan Elektronis (PPE): kegiatan pelayanan kas atau non kas yang dilakukan dengan menggunakan sarana mesin elektronis yang berlokasi baik di dalam maupun di luar kantor UUS, yang dapat melakukan pelayanan antara lain penarikan atau penyetoran secara tunai, pembayaran melalui pemindah bukuan, transfer antar bank dan/atau memperoleh informasi mengenai saldo/mutasi rekening nasabah, baik menggunakan jaringan dan/atau mesin miliki BUK yang memiliki UUS sendiri maupun melalui kerjasama BUK yang memiliki UUS dengan pihak lain, antara lain Anjungan Tunai Mandiri (ATM) termasuk dalam hal ini adalah Automatic Deposit Machine (ADM) dan Electronic Data Capture (EDC)

Unit Usaha Syariah yang dimiliki oleh bank konvensional semakin tahun semakin berkembang dan bertumbuh, seiring dengan banyaknya dengan jumlah asset yang dimiliki.

1. Perkembangan

Perkembangan merupakan proses yang terus menerus menuju suatu pembentukan yang terorganisir pada taraf yang lebih tinggi, berdasarkan pertumbuhan yang telah terjadi. Perkembangan selalu menyangkut pada perubahan yang lebih kompleks, berkaitan dengan berbagai kemajuan dan perubahan ke tingkat yang lebih tinggi dalam organisasi dan diferensiasi kehidupan. Dalam ekonomi, perkembangan diartikan sebagai peningkatan pendapatan per kapita masyarakat untuk setiap tingkat pertambahan penduduk. Sedangkan dalam suatu perbankan perkembangan dapat ditandai dengan semakin canggihnya teknologi yang dimiliki, sarana prasarana, dan sejenisnya yang dijadikan pendukung dalam kematangan suatu pelayanan di bank tersebut.

2. Pertumbuhan

Pertumbuhan berhubungan dengan transformasi data kuantitatif yakni eskalasi kenaikan ukuran dan struktur. Pertumbuhan merupakan perubahan sebagai hasil dari proses pematangan arti-arti fisik yang berlangsung secara normal dalam suatu waktu tertentu. Pertumbuhan biasanya digunakan untuk menjelaskan proses perubahan (penambahan) aspek-aspek yang lebih bersifat fisik, sederhana, dan konkrit. Pertumbuhan ekonomi diartikan sebagai kenaikan pendapatan nasional terhadap tingkat pertumbuhan penduduk dalam suatu struktur ekonomi. Dalam perbankan sendiri, pertumbuhan dapat dilihat dari jumlah jaringan kantor yang semakin luas, jumlah tenaga kerjanya, dan hal-hal lain sejenisnya.

3. Aset 
Aset merupakan segala sesuatu yang dipunyai oleh perusahaan baik berwujud maupun tidak berwujud yang bernilai dan mendatangkan manfaat. Manfaat tersebut diantaranya yaitu manfaat ekonomi yang dapat dirasakan untuk masa depan baik secara langsung ataupun tidak langsung. Berdasarkan PSAK No. 16 Revisi Tahun 2011, aset merupakan semua kekayaan yang dimiliki oleh seseorang atau perusahaan baik berwujud maupun tak berwujud yang berharga atau bernilai yang akan mendatangkan manfaat bagi seseorang atau perusahaan tersebut.

4. Jaringan Kantor

Jaringan adalah himpunan koneksi antar dua bagian atau lebih yang saling berhubungan dengan media transmisi yang tersedia, dimana keduanya saling bertukar data atau informasi, berbagai resource yang dimiliki, seperti halnya file dan informasi penting lainnya. Jadi, jaringan kantor dapat didefinisikan sebagai beberapa tempat kegiatan suatu perusahaan atau instansi yang saling berhubungan melalui media yang tersedia dalam berbagi informasi dan data.

Mahfudhotin (2019) telah meneliti tentang pertumbuhan tenaga kerja dan jaringan kantor terhadap perkembangan asset perbankan syariah namun belum adanya penelitian terhadap unit usaha syariah.

Dari uraian di atas maka peneliti menganalisis dengan judul "Analisis Jaringan Kantor dan Pertumbuhan Tenaga Kerja Terhadap Total Aset Unit Usaha Syariah" Penelitian ini didukung dengan penggunaan paket program SPSS. Paket program SPSSS (Statistical Product and service Solution) adalah paket program yang mendukung analisis dalam bidang statistika, riset operasi, analisis ekonomi, time series dan lain-lain. Rumusan masalah dalam penelitian ini adalah (1) Bagaimana model persamaan Analisis Jaringan Kantor dan Pertumbuhan Tenaga Kerja Terhadap Total Aset Unit Usaha Syariah (2) Bagaimana kebaikan model yang dihasilkan oleh regresi linier berganda pada Analisis Jaringan Kantor dan Pertumbuhan Tenaga Kerja Terhadap Total Aset Unit Usaha Syariah Tujuan dari penelitian ini adalah Mengetahui model persamaan regresi linier berganda Analisis Jaringan Kantor dan Pertumbuhan Tenaga Kerja Terhadap Total Aset Unit Usaha Syariah dan kebaikan model yang dihasilkan oleh regresi linier berganda pada Analisis Jaringan Kantor dan Pertumbuhan Tenaga Kerja Terhadap Total Aset Unit Usaha Syariah

Analisis regresi berberganda adalah pengembangan analisis regresi sederhana. Kegunaannya yaitu untuk meramalkan nilai variabel terikat (Y) apabila variabel bebasnya (X) dua atau lebih. Analisis regresi berganda adalah alat untuk meramalkan nilai pengaruh dua variabel bebas atau lebih terhadap satu variabel terikat (untuk membuktikan ada tidaknya hubungan fungsional atau hubungan kausal antara dua atau lebih variabel bebas $\mathrm{X}_{1}, \mathrm{X}_{2}, \ldots, \mathrm{X}_{\mathrm{i}}$ terhadap suatu variabel terikat $\mathrm{Y}$. Persamaan regresi berganda dirumuskan sebagai berikut:

1. Dua variabel bebas:

$$
\hat{Y}=a+b_{1} X_{1}+b_{2} X_{2}
$$

2. Tiga variabel bebas

$$
\hat{Y}=a+b_{1} X_{1}+b_{2} X_{2}+b_{3} X_{3}
$$

3. n variabel bebas:

$$
\hat{Y}=a+b_{1} X_{1}+b_{2} X_{2}+\cdots+b_{n} X_{n}
$$

Nilai-nilai pada persamaan regresi berganda untuk dua variabel bebas dapat ditentukan sebagai berikut :

$b_{1}=\frac{\left(\sum x_{2}{ }^{2}\right)\left(\sum x_{1} y\right)-\left(\sum x_{1} x_{2}\right)\left(\sum x_{2} y\right)}{\left(\sum x_{1}{ }^{2}\right)\left(\sum x_{2}{ }^{2}\right)-\left(\sum x_{1} x_{2}\right)^{2}}$

$b_{2}=\frac{\left(\sum x_{1}^{2}\right)\left(\sum x_{2} y\right)-\left(\sum x_{1} x_{2}\right)\left(\sum x_{1} y\right)}{\left(\sum x_{1}{ }^{2}\right)\left(\sum x_{2}^{2}\right)-\left(\sum x_{1} x_{2}\right)^{2}}$

$a=\frac{\sum Y}{n}-b_{1}\left(\frac{\sum X_{1}}{n}\right)-b_{2}\left(\frac{\sum X_{2}}{n}\right)$

Nilai-nilai $a, b_{1}$, dan $b_{2}$ pada persamaan regresi berganda untuk tiga variabel bebas dapat ditentukan dari rumus-rumus berikut (Sudjana, 1996: 77):

$\sum x_{1} y=b_{1} \sum x_{1}{ }^{2}+b_{2} \sum x_{1} x_{2}+b_{3} \sum x_{1} x_{3}$

$\sum x_{2} y=b_{1} \sum x_{1} x_{2}+b_{2} \sum x_{2}{ }^{2}+b_{3} \sum x_{2} x_{3}$

$\sum x_{3} y=b_{1} \sum x_{1} x_{2}+b_{2} \sum x_{2} x_{3}+b_{3} \sum x_{3}{ }^{2}$

$a=\bar{Y}-b_{1} \bar{X}_{1}-b_{2} \bar{X}_{2}-b_{3} \bar{X}_{3}$

Sebelum rumus-rumus di atas digunakan, terlebih dahulu dilakukan perhitungan-perhitungan yang secara umum berlaku rumus:

$\sum x_{i}^{2}=\sum X_{i}^{2} \frac{\left(\sum X_{i}\right)^{2}}{n}$

$\sum y^{2}=\sum Y^{2}-\frac{\left(\sum Y\right)^{2}}{n}$

$\sum x_{i} y=\sum X_{i} Y-\frac{\sum X_{i} \sum Y}{n}$

$\sum x_{i} x_{j}=\sum X_{i} X_{j}-\frac{\sum X_{i} \sum X_{j}}{n}$

Regresi dalam pengertian moderen ialah sebagai kajian terhadap ketergantungan satu variabel, yaitu variabel tergantung terhadap satu atau lebih variabel lainnya atau yang disebut sebagai variabel - variabel eksplanatori dengan tujuan untuk membuat estimasi dan / atau memprediksi rata - rata populasi atau nilai rata-rata variabel tergantung dalam kaitannya dengan nilai - nilai yang sudah diketahui dari variabel ekslanatorinya. Selanjutnya menurut Gujarati meski analisis regresi berkaitan dengan ketergantungan atau dependensi satu variabel terhadap variabel - variabel lainnya hal tersebut tidak harus menyiratkan sebab - akibat (causation) Gujarati (2009). Analisis regresi 
memiliki peranan yang penting dalam berbagai bidang ilmu pengetahuan. Kebanyakan analisis regresi bergantung pada metode kuadrat terkecil untuk mengestimasi parameter-parameternya dalam model regresi tetapi metode ini biasanya dibentuk dengan beberapa asumsi, seperti tidak ada autokorelasi, tidak terjadi multikolinearitas, homoskedastisitas, dan error berdistribusi normal.

Uji Autokorelasi bertujuan untuk mengetahui apakah dalam model regresi ada regresi antar kesalahan pengganggu pada periode $(\mathrm{t})$ dengan periode $\mathrm{t}-1$ (sebelumnya). Jika terjadi korelasi maka terdapat masalah korelasi. Masalah ini timbul karena residual (kesalahan pengganggu) tidak bebas dari satu observasi ke observasi lainnya. Model regresi yang baik adalah yang bebas dari autokorelasi. Cara yang dapat digunakan untuk mendeteksi ada atau tidaknya autokorelasi adalah dengan uji Durbin Watson (DW). Untuk pengambilan keputusan ada atau tidaknya autokorelasi dalam suatu model dapat digunakan patokan nilai dari DW hitung mendekati angka 2 . Jika nilai DW hitung mendekati atau sekitar 2 maka model tersebut terbebas dari asumsi klasik autokorelasi (Ghozali, 2018:111). Kriteria pengambilan keputusan pengujian autokorelasi adalah sebagai berikut:

a. Nilai DW antara 0 sampai 1,5 berarti terdapat Autokorelasi positif.

b. Nilai DW antara 1,5 sampai 2,5 berarti tidak ada autokorelasi.

c. Nilai DW antara 2,5 sampai 4 berarti terdapat Autokorelasi negatif.

Uji multikolinearitas dilakukan untuk mengetahui apakah antara variabel bebas terjadi multikolinier atau tidak dan apakah pada regresi ditemukan adanya korelasi yang tinggi atau sempurna antar variabel bebas (Ghozali, 2018:107). Model regresi yang baik yaitu model yang terbebas dari multikolinearitas. Ada tidaknya multikolinearitas dapat dideteksi dengan (1) nilai $\mathrm{R}$ square $\left(R^{2}\right)$ sangat tinggi, tetapi secara sendirisendiri regresi antara variabel-variabel independen dengan dependen variabel tidak signifikan. (2) korelasi antara variabel-variabel independen sangat tinggi diatas 0,80 .

Uji heteroskesdasitas bertujuan menguji apakah dalam model regresi terjadi ketidaksamaan varians dari residual satu pengamatan ke pengamatan lain tetap maka disebut homokesdasitas dan jika berbeda disebut heteroskedastisitas (Ghozali, 2018:137). Model regresi yang baik adalah yang homokedastisitas atau tidak terjadi heteroskedastisitas. Untuk menguji heterokedastisitas menggunakan uji Glejser. Ada atau tidaknya heteroskedastisitas dapat dilihat dari probabilitas signifikansinya, jika nilai signifikansinya diatas tingkat kepercayaan 5\% maka dapat disimpulkan tidak mengandung adanya heteroskedastisitas (Ghozali, 2018:142)

Menurut Ghozali (2018:161) uji normalitas adalah pengujian yang bertujuan untuk mengetahui apakah variabel bebas maupun terikat mempunyai distribusi yang normal atau tidak. Model regresi yang baik adalah regresi yang distribusi normal atau mendekati normal (Ghozali, 2018). Untuk menguji normalitas dalam penelitian ini menggunakan One Sample Kolgomorov Sminov Test. Dasar pengembalian keputusan adalah jika 2tailed >0,05, maka model regresi memenuhi asumsi normalitas dan sebaliknya.

\section{METODE PENELITIAN}

Metode yang digunakan pada penelitian ini adalah fokus penelitian, studi pustaka, perumusan masalah, pengumpulan data, pemecahan masalah, dan menarikan kesimpulan.

Data yang digunakan dalam penelitian ini merupakan data sekunder yang di dapat melalui situs resmi (laporan tahunan) Otoritas Jasa Keuangan dari januari 2019 - Desember 2019 yang terdiri dari: a. Aset (satuan milyar rupiah), b. Jaringan kantor (unit), c. Tenaga Kerja (orang). Fokus penelitian yang dilakukan dalam penelitian ini yaitu: (1) penelitian menggunakan model Regresi linier Berganda. (2) penelitian didukung dengan bantuan program SPSS (statistical product and service solutions). (3) variabel yang digunakan adalah perkembangan aset, jaringan kantor dan tenaga kerja unit usaha syariah tahun 2019.

Metode statistik yang digunakan dalam analisis jaringan kantor dan tenaga kerja terhadap pertumbuhan dan perkembangan asset adalah regresi linier berganda, dengan tahap sebagai berikut:

1. Melakukan Analisis deskriptif pada data.

2. Melakukan uji asumsi klasik: multikolinieritas, Autokorelasi dan Heterokedastisitas.

3. Melakukan uji asumsi regresi: uji normalitas dan penentuan model.

4. Melakukan uji kebaikan model pada model regresi yang telah didapat.

\section{HASIL DAN PEMBAHASAN}

Dalam penelitian ini, langkah pertama yang dilakukan adalah mendeskripsikan data adalah perkembangan aset, jaringan kantor dan tenaga kerja unit usaha syariah tahun 2019. selanjutnya akan dilakukan uji asumsi klasik dan uji asumsi Regresi 


\subsection{Data}

Penelitian ini didasarkan pada data yang bersumber dari OJK tahun 2019. Analisis perhitungan nantinya akan dengan menggunakan program statistik yang bernama SPSS dengan variabel Aset, Jaringan Kantor dan Tenaga Kerja pada unit usaha Syariah.

Tabel 1. Data Aset, Jaringan Kantor dan Tenaga Kerja unit usaha Syariah Tahun 2019

\begin{tabular}{cccc}
\hline Bulan & Aset & $\begin{array}{c}\text { Jaringan } \\
\text { Kantor }\end{array}$ & $\begin{array}{c}\text { Tenaga } \\
\text { Kerja }\end{array}$ \\
\hline Januari & 155399 & 354 & 4938 \\
Februari & 158277 & 359 & 5042 \\
Maret & 161758 & 364 & 5074 \\
April & 161638 & 368 & 5198 \\
Mei & 159194 & 370 & 5045 \\
Juni & 163944 & 372 & 5089 \\
Juli & 160437 & 374 & 4997 \\
Agustus & 162218 & 375 & 5055 \\
September & 165385 & 374 & 5178 \\
Oktober & 166190 & 376 & 4037 \\
November & 172279 & 378 & 5233 \\
Desember & 174200 & 381 & 5186 \\
\hline
\end{tabular}

Sumber: OJK 2019

Dari tabel diatas dapat dilihat bahwa asset yang dimiliki oleh unit usaha Syariah cenderung mengalami kenaikan pada setiap bulan.

\subsection{Uji Asumsi Klasik}

Uji asumsi klasik adalah persyaratan statistik yang harus dipenuhi pada analisis regresi linear berganda. uji asumsi klasik yang digunakan yaitu uji multikolinearitas, uji heteroskedastisitas dan uji autokorelasi dengan menggunakan program spss sehingga diperoleh hasil sebagai berikut:

a. Multikolinearitas

Uji multikolinearitas bertujuan untuk menguji apakah dalam model regresi terdapat korelasi antar variabel independent. Teknik yang dapat digunakan untuk mendeteksi adanya multikolinearitas diantaranya adalah pemeriksaan matriks korelasi, nilai VIF dan TOL tapi dalam penelitian ini peneliti hanya melihat nilai VIF dan TOL untuk mendeteksi adanya multikolinearitas pada data. Berikut nilai Variance Inflation Factor (VIF) dan TOL.

Tabel 2. Nilai TOL dan VIF

\begin{tabular}{lrcc}
\hline \multicolumn{1}{c}{ Variable } & TOL & VIF \\
\hline Jaringan Kantor $\left(X_{1}\right)$ & 0.999 & 1.001 \\
Tenaga Kerja $\left(X_{2}\right)$ & 0.999 & 1.001 \\
\hline Variabel $X_{1}$ dan & $X_{2}$ & tidak & mengandung
\end{tabular}
multikolinieritas sebab dari nilai VIF $<10$ yaitu
1.001 dan 1.001 dan nilai TOL > 0.1 yaitu 0.999 dan 0.999 .

b. Autokorelasi

Hipotesis:

$H_{0}$ : Terjadi autokorelasi

$H_{1}$ : Tidak terjadi autokorelasi

Tingkat signifikansi $\alpha=0.05$

Kriteria:

Jika $d>d u$, maka $H 0$ diterima (tidak ada autokorelasi).

Jika $d<$, maka $H 0$ ditolak (ada autokorelasi positif).

Jika $4-d>$, maka $H 0$ diterima (tidak ada autokorelasi negatif).

Jika $4-d<$, maka $H 0$ ditolak (ada autokorelasi negatif).

Tabel 3. Autokorelasi

\begin{tabular}{c|c}
\hline Durbin-Watson D & 0.728 \\
Number of Observation & 12 \\
\hline
\end{tabular}

Berdasarkan output SPSS di atas diperoleh nilai Durbin-Watson D sebesar 0.728. Langkah selanjutnya menentukan nilai $d L$ dan $d u$ dengan taraf nyata 0.05 , observasi sebanyak $\mathrm{n}=12$ data, dan $\mathrm{K}$ adalah jumlah variabel independentnya sebanyak 2, dengan melihat nilai tabel Durbin_Watson (dengan Taraf signifikansi 0.05) maka diperoleh nilai $d L=0.8122$ sedangkan nilai $d u=1.5794$. Karena $d=0.728<\mathrm{L}=0.8122$ maka $H_{0}$ Tolak (tidak ada autokorelasi).

c. Uji Heteroskedastisitas

Untuk mendeteksi ada tidaknya heteroskedastisitas dengan melihat pola titik-titik pada plots regresi. Jika titik-titik menyebar dengan pola tidak jelas di atas dan di bawah angka 0 pada sumbu Y maka tidak terjadi masalah heteroskedastisitas. Berikut output plot dari program SPSS terlihat pada gambar 1.

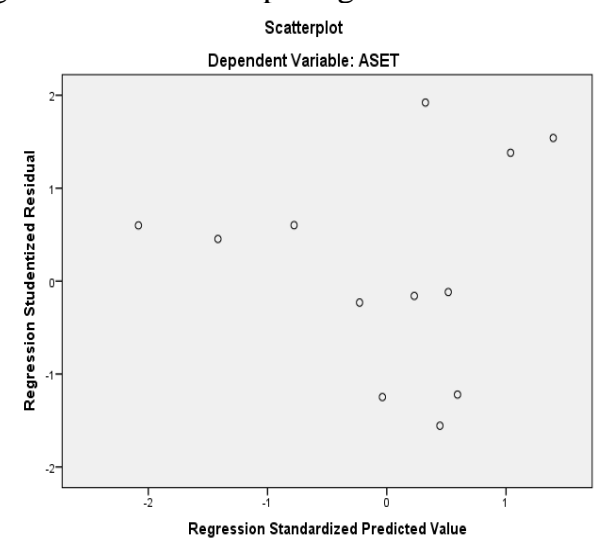

Gambar 1 Scatterplot Uji Heteroskedastisitas 3.3 Uji Asumsi Regresi

a. Uji Normalitas 
Model regresi yang baik jika distribusi data normal atau mendekati normal. Hal ini dapat dideteksi dengan melihat Plot Grafik Normal $p-p$

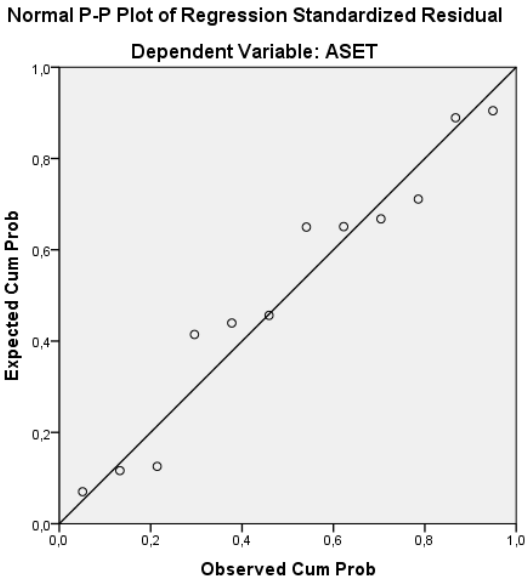

Gambar 2 Grafik Normal $p-p$

b. Model Regresi Berganda

Dari data perkembangan aset, jaringan kantor dan tenaga kerja unit usaha syariah tahun 2019 dilakukan regresi linear dengan menggunakan program spss. analisis regresi bertujuan untuk mengetahui hubungan variabel-variabel dependent terhadap variabel independentnya

Tabel 3. Parameter Estimates

\begin{tabular}{crrcc}
\hline $\begin{array}{c}\text { Variabl } \\
\text { e }\end{array}$ & $\begin{array}{r}\text { Parameter } \\
\text { Estimates }\end{array}$ & $\begin{array}{c}\text { Standart } \\
\text { Error }\end{array}$ & t & Value \\
\hline & -56634.7 & 50854.338 & -1.11 & 0.294 \\
$X_{1}$ & 1.763 & 3.220 & 0.548 & 0.597 \\
$X_{2}$ & 570.217 & 128.545 & 4.436 & 0.002 \\
\hline
\end{tabular}

Uji t secara parsial menurut V.W Sujareweni (2014) jika nilai $t_{\text {hitung }}>t_{\text {tabel }}$ maka artinya variabel independen $(\mathrm{X})$ berpengarh secara parsial terhadap variabel dependen (Y)

Dengan uji $\mathrm{t}$ secara parsial untuk variabel $X_{1}$ (jaringan Kantor):

$H_{0}$ : jaringan Kantor berpengaruh terhadap aset unit usaha syariah

$H_{1}$ : jaringan Kantor tidak berpengaruh aset unit usaha syariah

Pengujian dengan $\alpha=5 \% \mathrm{n}=12 \mathrm{k}=2$ maka di dapat nilai $t_{\text {tabel }}=2.2621$

Karena $t_{\text {hitung }}<t_{\text {tabel }}$ maka dapat disimulkan bahwa jaringan Kantor tidak berpengaruh aset unit usaha syariah

Dengan uji t secara parsial untuk variabel $X_{1}$ (Tenaga Kerja):

$H_{0}$ : Tenaga kerja berpengaruh terhadap aset unit usaha syariah

$H_{1}$ : Tenaga Kerja tidak berpengaruh aset unit usaha syariah

Pengujian dengan $\alpha=5 \% \mathrm{n}=12 \mathrm{k}=2$ maka di dapat nilai $t_{\text {tabel }}=2.2621$
Karena $t_{\text {hitung }}>t_{\text {tabel }}$ maka dapat disimpulkan bahwa tenaga kerja berpengaruh aset unit usaha syariah

Tabel 4. ANOVA

\begin{tabular}{|c|c|c|c|c|c|c|}
\hline & Model & $\begin{array}{c}\text { Sum of } \\
\text { Squares }\end{array}$ & df & $\begin{array}{l}\text { Mean } \\
\text { Square }\end{array}$ & $\mathbf{F}$ & Sig. \\
\hline \multirow{5}{*}{1} & Regres & 2279325 & 2 & 1139662 & 9.911 & 0.005 \\
\hline & & 36.261 & & 68.130 & & \\
\hline & residua & 1034920 & 9 & 1149911 & & \\
\hline & 1 & 52.656 & & 6.962 & & \\
\hline & Total & $\begin{array}{r}3314245 \\
88.917\end{array}$ & 11 & & & \\
\hline
\end{tabular}

Dengan uji F secara parsial simultan berdasarkan nilai signifikansi, menurut imam ghozali (2011) jika nilai sig $<0.05$ maka artinya variabel independen $\left(X_{1} \operatorname{dan} X_{2}\right)$ berpengaruh terhadap variabel dependen $(Y)$. Dapat dilihat pada tabel 4 nilai sig $=0.005$ karena $0.005<0.05$ maka variabel indepeneden (jaringan kantor dan tenaga kerja) berpengaruh secara simultan terhadap variabel dependen (unit usaha syariah)

Berdasarkan tabel 3 hasil persamaan regresi linier dugaan yang diperoleh adalah sebagai berikut:

$$
\hat{y}=-56634.7+1.763 X_{1}+570.217 X_{2}
$$

Persamaan regresi di atas dapat dijelaskan sebagai berikut:

$>$ Konstanta sebesar -56634.7; artinya jika Jaringan Kantor $\left(\mathrm{X}_{1}\right)$ dantenaga kerja $\left(\mathrm{X}_{2}\right)$ nilainya adalah 0 , maka Aset ( $Y^{\prime}$ ) nilainya adalah Rp. $-56634,7$.

Koefisien regresi variabel Jaringan Kantor $\left(\mathrm{X}_{1}\right)$ sebesar 1.763; artinya jika variabel bebas lain nilainya tetap dan Jaringan Kantor mengalami kenaikan 1\%, maka aset (Y') akan mengalami kenaikan sebesar Rp. 1,763.

Koefisien regresi variabel tenaga kerja $\left(\mathrm{X}_{2}\right)$ sebesar 570.217; artinya jika variabel bebas lain nilainya tetap dan tenaga kerja mengalami kenaikan 1\%, maka harga aset (Y') akan mengalami peningkatan sebesar Rp.6570,217. Koefisien bernilai positif artinya terjadi hubungan positif antara tenaga kerja dengan aset, semakin naik tenaga kerja maka semakin meningkat aset.

\subsection{Uji Kebaikan Model}

Koefisien determinasi $R^{2}$ dapat digunakan untuk menentukan kebaikan model. Semakin nilai $R^{2}$ mendekati satu maka semakin tinggi pengaruh variabel independent terhadap variabel dependent, yang berarti semakin baik kecocokan model dengan data

$\frac{\frac{\text { Tabel 5. Nilai } R^{2}}{\text { R Square }}}{0.688}$


Berdasarkan tabel 5 dapat dilihat bahwa nilai $R^{2}$ yang dihasilkan adalah 0.688 artinya model regresi linier berganda dalam permasalahan ini memiliki kecocokan model sebesar $68.8 \%$.

\section{KESIMPULAN DAN SARAN \\ a. Kesimpulan}

Penelitian ini menggunakan regresi linier berganda yaitu model regresi berganda yang variabel dependennya merupakan fungsi linier dari beberapa variabel bebas, yakni untuk mengetahui keakuratan hubungan antara perkembangan aset unit usaha syariah (variabel dependen) dengan pertumbuhan tenaga kerja dan jaringan kantor sebagai variabel yang mempengaruhi (variabel independen). berdasarkan data dari otoritas jasa keuangan periode tahun 2019 dengan menggunakan metode penelitian asosiatif diperoleh hubungan pertumbuhan tenaga kerja dan jaringan kantor terhadap perkembangan aset perbankan syariah yang sangat kuat yakni sebesar $68.8 \%$.

Ini juga dapat dilihat dari Uji F-Statistik yakni pengujian yang dilakukan untuk mengetahui secara bersama-sama variabel bebas berpengaruh secara signifikan atau tidak terhadap variabel terikat yakni nilai p-value nya sebesar $0.005<\alpha$ (0.05). Sehingga dapat dikatakan bahwa pertumbuhan tenaga kerja dan jaringan kantor terhadap perkembangan aset perbankan syariah memiliki hubungan yang linier

\section{b. Saran}

Penelitian ini masih mengandung keterbatasan terkait menggunakan data sekunder yang berasal dari Otoritas Jasa Keuangan 2019 dengan variabel-variabel yang digunakan hanya terbatas pada variabel pertumbuhan tenaga kerja dan jaringan kantor, maka perlu adanya penambahan variabel dan bahasan yang lebih mendalam.

\section{DAFTAR PUSTAKA}

Gozali, I. 2018. Aplikasi Analisis Multivariate dengan Program IBM SPSS 25. Edisi 9. Semarang: Undip

Gujarati, Damodar. 2009. Ekonometrika Dasar. Edisi Kelima. Erlangga. Jakarta.

Mahfudhotin. 2019. Analisa Pertumbuhan Tenaga Kerja dan Jaringan Kantor Terhadap Perkembangan Aset Perbankan Syariah, $\begin{array}{lllll}\text { el-Qist. } & \text { Vol } & 9 & \text { No } & 1\end{array}$ http://jurnalfebi.uinsby.ac.id/index.php/elq ist/article/view/220 diakses pada 25 jni 2020

Otoritas Jasa Keuangan. 2020. Statistik Perbankan Syaria, Jakarta : Penulis. Diakses dari https://www.ojk.go.id/id/kanal/syariah/dat a-dan-statistik/statistik-perbankansyariah/Documents/Pages/StatistikPerbankan-Syariah---Desember2019/SPS\%20Desember\%202019.pdf

Sudjana. 1996. Metode Statistika Bandung: Tarsito.

Sujarweni, V. Wiratna. 2014. Metode Penelitian: Lengkap, Praktis, dan Mudah Dipahami Yogyakarta: Pustaka Baru Press.

Sugiono. 2017. Metodologi Penelitian Kombinasi (Mixed Method). Jakarta: Alfabeta.

Zainuddin Ali. 2010. Hukum Perbakan Syariah. Jakarta: Sinar Grafika.

Supriyadi, E., Mariani, S. \& Sugiman. 2017. Perbandingan Metode Partial Least Square (PLS) dan Principal Component Regression (PCR) untuk Mengatasi Multikolinearitas pada Model Regresi Linear Berganda. Unnes Journal of Mathematics, 6(2): 117-128. 